\title{
BATAS WAKTU MENGQASAR SALAT BAGI MUSAFIR MENURUT ULAMA EMPAT MAZHAB
}

\section{THE TIME LIMIT OF QASAR SALAT FOR TRAVELERS ACCORDING TO THE FOUR SCHOOL OF ULAMA}

\author{
Rachmat bin Badani Tempo \\ Sekolah Tinggi Ilmu Islam dan Bahasa Arab (STIBA) Makassar \\ Email: rachmatbadani@stiba.ac.id \\ Nuraeni Novira \\ Sekolah Tinggi Ilmu Islam dan Bahasa Arab (STIBA) Makassar \\ Email: nuraeni@gmail.com \\ Auliya Ulhaq \\ Sekolah Tinggi Ilmu Islam dan Bahasa Arab (STIBA) Makassar \\ Email: auliya@gmail.com
}

\begin{tabular}{|c|c|}
\hline Keywords : & ABSTRACT \\
\hline $\begin{array}{l}\text { Time, Qasar, Salat, Ulama, } \\
\text { Mazhab }\end{array}$ & $\begin{array}{l}\text { The purpose of this research; 1) to find out the opinions of four mazhab } \\
\text { scholars on the issue of the time limit for a traveler to be able to make } \\
\text { up his prayers, the background of the differences and the opinion that is } \\
\text { rajih. This research uses qualitative research through library research. } \\
\text { Methods of normative theological approach and comparative approach. } \\
\text { Research results; First, the Hanafi Mazhab: a traveler can make up his } \\
\text { prayers for } 15 \text { days. Maliki and Shafi'i Mazhab; A traveler may make up } \\
\text { his prayers for } 4 \text { days other than the day he arrives and leaves. Hanbali } \\
\text { Mazhab: a traveler may make up his prayer for } 4 \text { days or } 20 \text { times of } \\
\text { obligatory prayer, including the day of arrival and departure. The rajih } \\
\text { views are the Shafi'i and Maliki Mazhab; Second, differences of opinion } \\
\text { occur because this issue includes issues that are not explicitly discussed } \\
\text { in the Shari'a ('amrun maskuutun 'anhu fi al-syar'i) so that each opinion } \\
\text { is only guided by the conditions and actions quoted from the Prophet. } \\
\text { The reason is because this issue is a problem that is not explicitly } \\
\text { discussed in the Shari'a ('amrun maskuutun 'anhu fi al-syar'i). This } \\
\text { triggers a difference of opinion regarding the traditions of the Prophet } \\
\text { Muhammad. about traveling; Third, the opinion that is rajih in this } \\
\text { matter is the opinion of the Shafi'i Mazhab and the Maliki Mazhab. }\end{array}$ \\
\hline \multirow{2}{*}{$\begin{array}{l}\text { Kata kunci : } \\
\text { Waktu, Qasar, Salat, Ulama, } \\
\text { Mazhab }\end{array}$} & ABSTRAK \\
\hline & $\begin{array}{l}\text { Penelitian ini bertujuan untuk mengetahui pendapat empat ulama } \\
\text { mazhab dalam masalah batas waktu seorang musafir dapat mengqasar } \\
\text { salatnya, latar belakang perbedaannya dan pendapat yang rajih. } \\
\text { Penelitian ini menggunakan metode pendekatan teologis normative dan } \\
\text { pendekatan perbandingan (comparative approach) Hasil penelitian; } \\
\text { Pertama, Mazhab Hanafi: seorang musafir boleh mengqasar salatnya } \\
\text { selama } 15 \text { hari. Mazhab Maliki dan Syafii; seorang musafir boleh } \\
\text { mengqasar salatnya selama } 4 \text { hari selain hari kedatangan dan } \\
\text { kepergiannya. Mazhab Hanbali: seorang musafir boleh mengqasar } \\
\text { salatnya selama } 4 \text { hari atau } 20 \text { waktu salat wajib, termasuk di dalamnya } \\
\text { hari kedatangan dan kepergiannya. Pandangan yang rajih adalah Mazhab } \\
\text { Syafii dan Maliki; Kedua, Perbedaan pendapat terjadi karena sebabnya }\end{array}$ \\
\hline
\end{tabular}




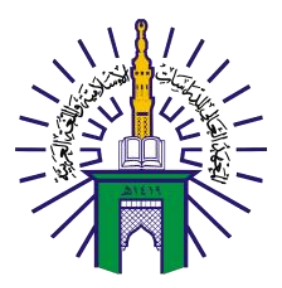

\section{BUSTANUL FUQAHA: \\ JURNAL BIDANG HUKUM ISLAM \\ Vol. 2 No. 1 (2021): Hal. 500-508 \\ EISSN: 2723-6021 \\ Website: https://journal.stiba.ac.id}

Diterima: 4 September 2021; Direvisi: 22 Oktober 2021; Disetujui: 22 November 2021; Tersedia online: 3 Desember 2021

How to cite: Rachmat bin Badani Tempo, Nuraeni Novira, Auliya Ulhaq, "Batas Waktu Menqasar Salat bagi Musafir Menurut Ulama Empat Mazhab," BUSTANUL FUQAHA: Jurnal Bidang Hukum Islam Vol. 2, No. 3 (2021): 500-508. doi: 10.36701/bustanul.v2i3.407.

\section{PENDAHULUAN}

Agama Islam merupakan agama yang sempurna. Agama yang haq ini telah disempurnakan oleh Allah swt. dalam segala segi, segala yang dibutuhkan hamba untuk kehidupan dunia dan akhiratnya. Tidak aka nada yang luput satu percakapan pun melainkan Islam telah mengaturnya. Allah swt. berfirman dalam Q.S. al-Maidah/5: 3.

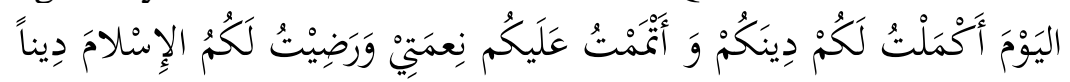

Terjemahnya:

"Pada hari ini telah Aku sempurnakan agamamu untukmu, dan telah Aku cukupkan nikmat-Ku bagimu, dan telah Aku ridai Islam sebagai agamamu."1

Al-Hafiz Ibnu Kasir dalam tafsirnya berkata, "Ini merupakan nikmat Allah yang terbesar bagi umat ini. Allah telah menyempurnakan bagi mereka agama mereka sehingga mereka tidak butuh kepada selain Islam. Karena itulah Allah menjadikan Muhammad saw. sebagai penutup para Nabi dan Rasul. Allah mengutusnya untuk kalangan manusia dan jin. Maka tidak ada perkara yang haram kecuali apa yang dia haramkan, dan tidak ada agama kecuali apa yang dia syariatkan. Segala sesuatu yang dia kabarkan adalah kebenaran dan kejujuran tidak ada kedustaan padanya."

Dari kesempurnaan agama ini dan kemudahan yang ada di dalamnya, Allah swt. telah menetapkan hukum-hukum safar serta mengajarkan adab-adabnya di dalam kitabNya dan sunah nabi-Nya. Oleh karena itu, ada beberapa keringanan (rukhsah) yang diberikan oleh syariat kepada orang yang dalam perjalanan (musafir). Rukhsah adalah apa yang dimudahkan Allah bagi hamba-Nya dan diluaskan dari masa-masa yang sulit dengan meninggalkan sebagian kewajiban dan membolehkan sebagian yang diharamkan. ${ }^{3}$ Orang yang melakukan perjalanan jauh mendapatkan keringanan untuk mengqasar salat yakni meringkas salat yang empat rakaat menjadi dua rakaat. Keringanan

'Departemen Agama, Al-Quran Terjemah (Banten: CV. Al-Fatih Berkah Cipta, 2016), h. 107.

${ }^{2}$ Abu al-Fida' 'Isma'il Ibnu 'Umar Ibnu Kasir, Tafsir al-Quran al-Âzım, Jilid III (Cet. III; t.tp.: Dâr al-Tayyibah li al-Nusyr wa al-Tauzf, 1420H/1999 M), h. 26.

${ }^{3}$ Muhammad ibn 'Ismail ibn Salah ibn Muhammad al-San'am, Subul al-Salam, Jilid I (Dar al-Hadis, t.th), h. 387 . 


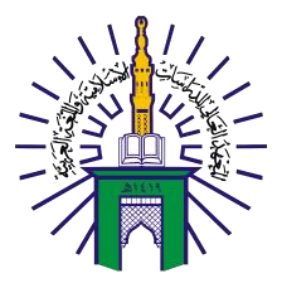

\section{BUSTANUL FUQAHA: \\ JURNAL BIDANG HUKUM ISLAM \\ Vol. 2 No. 1 (2021): Hal. 500-508 \\ EISSN: 2723-6021 \\ Website: https://journal.stiba.ac.id}

mengqasar salat diterangkan oleh Allah swt. dalam Q.S. al-Nisa/4 : 101.

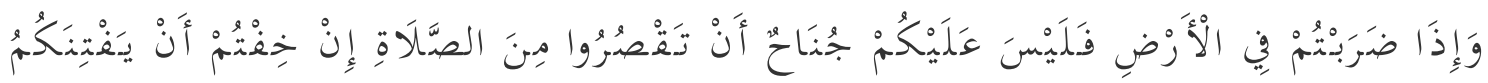

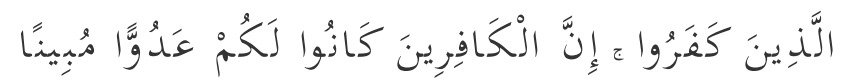

Terjemahnya:

Dan apabila kamu bepergian di muka bumi, maka tidaklah mengapa kamu mengqasar salat (mu), jika kamu takut diserang orang-orang kafir. Sesungguhnya orang-orang kafir itu adalah musuh yang nyata bagimu. ${ }^{4}$

Ayat ini menjelaskan bahwa qasar salat dibolehkan, baik dalam kondisi ketakutan atau aman. Akan tetapi, mengaitkan salat qasar dengan rasa takut untuk menegaskan kondisi realnya, sebab hampir semua perjalanan Nabi saw. tidak terlepas dari rasa ketakutan. ${ }^{5}$ Imam Muslim meriwayatkan dalam Sahih-nya,

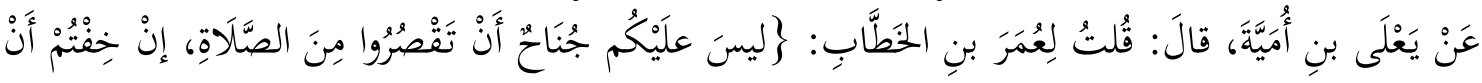

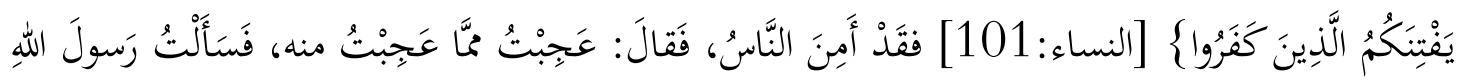

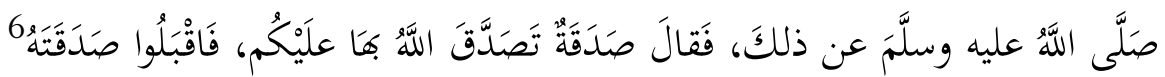

Artinya:

Ya'la bin Umayyah pernah menanyakan ayat tersebut kepada Amirul Mukminin Umar ibn al-Khattab ra. "Maka tidaklah mengapa kamu mengqasar salat (mu), jika kamu takut diserang orang-orang kafir". Saat ini orang-orang telah merasa aman. 'Umar berkata, "Aku juga pernah heran seperti kamu. Tapi saya pernah bertanya kepada Rasulullah saw. tentang hal itu. Rasulullah saw. menjawab "Itu adalah sedekah yang diberikan Allah kepada kalian, maka terimalah sedekahNya."

Oleh karena itu, meskipun safar yang dilakukan penuh dengan kemudahan dan kenyamanan, keringanan tersebut tetap berlaku. Bahkan hendaknya seseorang tetap mengambil keringanan itu. Karena itulah yang lebih afdal dan lebih dicintai oleh Allah. Namun jika salat (bermakmum) di belakang imam mukim yang salat sempurna (empat rakaat), musafir wajib mengikuti imam sehingga tetap salat sempurna sebagaimana biasa. Hal ini berdasar pada dalil tentang kewajiban mengikuti imam. ${ }^{7}$

Qasar berlaku untuk salat-salat empat rakaat, yaitu zuhur, asar dan isya, tidak ada qasar dalam salat magrib dan subuh. Tidak ada sebab untuk qasar ini kecuali perjalanan. Jadi selama dalam perjalanan seorang musafir boleh mengqasar salat, berapa pun lamanya. Namun ketika dia telah sampai di suatu tempat yang dituju, terdapat perbedaan

\footnotetext{
${ }^{4}$ Departemen Agama, Al-Quran Terjemah, h. 94.

${ }^{5}$ Wahbah bin Mustafa al-Zuhaili, Al-Fiqh al-Islami wa Adillatuh, Jilid II (Cet. IV; Damaskus: Dar al-Fikri, t.th.), h. 1335.

${ }^{6}$ Muslim ibn al-Hajjaj Abu al-Hassan al-Qusyairi al-Naisaburi, Al-Jami' al-Sahih, Jilid I (Beirut: Dar Ihya al-Turasi al-'Arabiy, t.th), h. 478.

${ }^{7}$ Asmaji Muchtar, Fatwa-Fatwa Imam asy-Syafi'i (Jakarta: Amzah, 2014), h. 120.
} 
pendapat di kalangan ulama mengenai penetapan batas waktu bolehnya musafir tersebut mengqasar salatnya. Dalam masalah ini, para ulama berselisih pendapat.

Rumusan masalah yang diangkat dalam kajian ini; Pertama, bagaimana pendapat empat ulama mazhab dalam masalah batas waktu seorang musafir dapat menqasar salatnya?; Kedua, bagaimana latar belakang perbedaan pendapat ulama mazhab dalam masalah ini?; dan Ketiga, bagaimana pendapat yang rajih dalam masalah ini? Kajian ini menggunakan penelitian kualitatif melalui studi kepustakaan (library research) dengan menggunakan metode pendekatan teologis normative dengan cara menelusuri dalil-dalil Al-Qur'an dan hadis serta pendapat para fukaha. Serta metode pendekatan perbandingan (comparative approach) dengan membandingkann pendapat di antara empat mazhab. Kajian ini bertujuan untuk mengetahui pendapat empat ulama mazhab dalam masalah batas waktu seorang musafir dapat mengqasar salatnya, untuk mengetahui latar belakang perbedaan pendapat ulama mazhab dalam masalah ini dan untuk mengetahui pendapat yang rajih dalam masalah ini.

Kajian awal terhadap pustaka atau karya-karya yang mempunyai relevansi terhadap topik yang akan dikaji diperlukan untuk mendukung penelaahan yang komprehensif. Di antaranya; a) "Penentuan Jarak Tempuh Perjalanan Untuk Jamak dan Qasar Salat bagi Musafir (Studi Komparatif antara Ibnu Taimiyah \& Ibnu Hazm) ”, karya Muhsin mahasiswa Program Studi Perbandingan Mazhab, Fakultas Syariah dan Hukum, UIN Ar-Raniry. Dalam tulisan ini dipaparkan pandangan Ibnu Taimiyah dan Ibnu Hazm dalam masalah jamak dan qasar salat bagi musafir dan istinbat mereka dalam hukum jamak dan qasar salat serta relevansinya dengan konteks kekinian.; b) "Hukum Mengqasar Salat bagi Musafir Menurut Imam Abu Hanlfah dan Imam Syafii”, karya Suhaimi bin Suib, mahasiswa Jurusan Perbandingan Mazhab dan Hukum, Fakultas Syariah dan Hukum, UIN Sultan Syarif Kasim, Riau. Dalam tulisan ini penulis menjelaskan hukum salat qasar menurut Imam Abu Hanifah dan Imam Syafii, dalil yang digunakan dalam menetapkan hukum salat qasar serta bagaimana analisis fikih muqaran terhadap pemikiran Imam Abu Hanifah dan Imam Syafii tentang hukum salat qasar serta mentarjih pendapat antara keduanya.

\section{PEMBAHASAN}

\section{Mengqasar Salat bagi Musafir}

Perkembangan hukum Islam tidak dapat dilepaskan dari perkembangan mazhabmazhab fikih yang terus berkembang dan menyebar. Sementara perkembangan mazhabmazhab fikih jelas sangat dipengaruhi dan didukung oleh usul fikih yang ada dalam setiap mazhab tersebut. ${ }^{8}$ Ulama mazhab fikih berbeda pendapat dalam persoalan batas waktu seorang musafir masih berhak mengqasar salatnya, selama musafir tersebut belum berniat untuk bermukim di suatu tempat dalam waktu tertentu. Para ulama fikih berbeda pendapat menjadi tiga pendapat dalam menentukan batas waktu ini. ${ }^{9}$

Mazhab Hanafi mengatakan seorang musafir dianggap bermukim dan dilarang mengqasar salat bila telah berniat untuk bermukim di sebuah daerah selama lima belas

${ }^{8}$ Muhammad Ikhsan, "Sejarah Mazhab Fikih di Asia Tenggara", Nukhbatul 'Ulum vol. 4, no. 67 (2018): h. 1.

9 Abu al-Walid Muhammad ibn Ahmad ibn Muhammad ibn Ahmad lbnu Rusyd, Bidayah alMujtahid wa Nihayah al-Muqtasid, Jilid I (t.Cet; Kairo: Dar al-Hadis, 1425 H/ 2004 M), h. 180. 


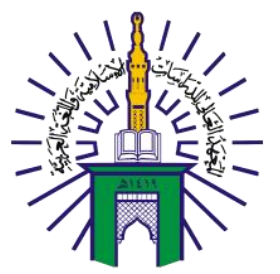

\section{BUSTANUL FUQAHA: \\ JURNAL BIDANG HUKUM ISLAM \\ Vol. 2 No. 1 (2021): Hal. 500-508 \\ EISSN: 2723-6021 \\ Website: https://journal.stiba.ac.id}

\section{BUSTANUL FUQAHA}

Jurnal Bidang Hukum Islam

hari atau lebih. Jika seorang musafir telah berniat waktu tersebut maka diharuskan menyempurnakan rakaat salatnya. Namun, jika berniat kurang dari lima belas hari maka musafir tetap mengqasar salatnya. ${ }^{10}$ Dalil mereka adalah analogi dengan lamanya waktu suci bagi wanita haid karena keduanya merupakan dua waktu yang diwajibkan untuk kembali kepada waktu aslinya. Waktu suci mewajibkan untuk mengganti apa saja yang gugur karena haid. Sedangkan bermukim mewajibkan untuk mengganti ibadah-ibadah yang gugur karena melakukan peijalanan. ${ }^{11}$

Batas waktu ini diriwayatkan dari Ibnu Abbas ra. dan Ibnu Umar ra. keduanya mengatakan;

$$
\begin{aligned}
& \text { قال: إذاًَ دخلتَ بلدةَ وَأنتَ مسافرَ وفيَ عزم كَأنَ تقيمَ بهاَ خمسةَ عشرَ يوما ، فأكمل الصَلاةَ، وإنَ } \\
& \text { كنت لَتدريَ متى تظعنَ فاقصر } 12
\end{aligned}
$$

Artinya:

"Jika kamu memasuki sebuah daerah dan kamu sedang bepergian, lalu kamu berniat untuk bermukim di daerah tersebut selama lima belas hari maka sempurnakanlah salat. Namun jika kamu tidak tahu kapan akan berangkat lagi maka tetap qasarlah salatmu!"

Jika seorang musafir menunggu untuk menyelesaikan suatu urusan, dibolehkan baginya mengqasar salat meskipun waktunya lama hingga bertahun-tahun. Siapa yang masuk ke sebuah daerah dan belum berniat untuk bermukim di daerah itu selama lima belas hari dan tetap bersiap-siap untuk melakukan perjalanan lagi, seraya berkata, "Besok atau lusa aku akan pergi dari sini" dan itu terus berlangsung hingga tahunan maka boleh baginya tetap menqasar salat. Karena diriwayatkan bahwa Ibnu Umar ra. pernah menetap di Azerbaijan selama enam bulan dan selama itu pula ia menqasar salatnya. Diriwayatkan pula dari sekelompok sahabat dengan redaksi seperti di atas. ${ }^{13}$ Jika tentara memasuki daerah perang dan mereka berniat untuk menetap di sana selama lima belas hari atau mereka mengepung sebuah kota atau benteng maka mereka diharuskan mengqasar salat dan tidak boleh menyempurnakan salatnya karena niatnya tidak sah. Sebab, pendatang itu selalu dalam kondisi ragu tidak tetap. Ia ragu antara mengalahkan musuh dan menetap atau justru dikalahkan oleh musuh dan lari menyelamatkan diri. ${ }^{14}$

Mazhab Syafii dan mazhab Maliki menyatakan bahwa apabila musafir sudah berniat untuk mukim di tempat tujuan selama empat hari, maka harus menyempurnakan (tidak meringkas) salat. ${ }^{15}$ Imam Syafii menetapkan untuk mukim pada suatu tempat

${ }^{10}$ Muhammad Ahmad ibn Abi Ahmad Abu Bakr 'Ila'uddin al-Samarqandi, Tuhfatu al-Fuqaha, Jilid I (Cet. II; Beirut: Dar al-Kitab al-'Ilmiyyah, 1414 H/ 1994 M), h.151.

${ }^{11}$ Wahbah bin Mustafa al-Zuhaili, Al-Fiqh al-Islami wa Adillatuhu, h. 1345.

${ }^{12}$ Abu Bakar bin Mas'ud bin Ahmad al-Kasani, Bad̄̄i 'u al-San̄̄'i fi Tartibi al-Syar'i, Jilid 1 (Bairut: Dár al-Kutubi 'Ilmiyati, 1986), h. 97.

13 Alauddin al-Samakhandi, Tuhfat al-Fuqaha, h. 150.

${ }^{14}$ Wahbah bin Mustafa al-Zuhaili, Al-Fiqh al-Islami wa Adillatuhu, h.1348.

${ }^{15}$ Syihabuddin Ahmad bin Hajar al-Haitami, Tuhfat al-Muhtaj bi Syarh al-Minhaj, Jilid 2 (Bairut: Dár al-Fikri, 2009), h. 410. Zakaria al-Ansari, Hasyiat al-Bujairimi, Jilid 1 (Bairut: Dár al-Fikri, 2009), h. 353. 
selama empat hari dan empat malam, tidak termasuk di dalamnya hari dimana musafir tersebut mengadakan perjalanan lalu masuk ke negeri itu pada sebagian hari tersebut dan tidak pula termasuk hari keluarnya dari negeri itu. ${ }^{16}$

Dalil hadis riwayat al-Alla' bin Hazrami, dia berkata, aku mendengar Rasulullah saw. bersabda,

$$
\text { يقيم المهاجر بمكة بعد قضاء نسكه ثلاثا } 17
$$

Artinya:

Orang-orang muhajirin untuk tinggal di Makkah setelah melakukan haji selama tiga hari. (HR Muslim)

Dalil yang lain adalah hadis yang diriwayatkan oleh Bukhari dan Muslim yang menyatakan bahwa "Orang yang berhijrah setelah menunaikan amalan-amalan hajinya, tinggal selama tiga hari. Dan ketika 'Umar ibn al-Khattab ra. mengusir orang-orang Yahudi dari Hijaz, ia mengizinkan siapa di antara mereka yang datang sebagai pedagang untuk tinggal selama tiga hari." Disebutkan dalam Nail al-Autar bahwa Kaum Muhajirin bermukim selama tiga hari telah menyelesaikan ibadah hajinya. Nabi saw. saat mukim di Mekkah untuk ibadah umrah selama tiga hari dan menqasar salatnya."18

Maliki dan Syafii tidak menghitung dua hari saat masuk dan keluar dari suatu daerah sesuai pendapat yang sahih dalam mazhab Syafii. Karena, hari pertama itu untuk menurunkan barang, sedang yang kedua untuk bersiap-siap berangkat. Keduanya merupakan aktivitas sebuah perjalanan. ${ }^{19}$ Sedangkan menurut Hanafi wajib bagi musafir untuk melaksanakan salat dengan dua rakaat pada salat farḍu yang empat rakaat apabila telah keluar dari deretan rumah-rumah yang ada di desanya yang menjadi tempat keluar. Atau melewati perkampungan dari sisi tempat keluar dari kotanya, walaupun ia belum melewatinya dari sisi lain karena bermukim itu berkaitan dengan masuknya maka bepergian juga berkaitan keluar darinya. ketentuan ini terus berlaku baginya sampai dia niat bermukim di suatu tempat selama 15 hari atau lebih. Maka ketika itu ia wajib menyempurnakan șalat. Namun, jika berniat kurang dari lima belas hari maka ia tetap boleh mengqasar șalatnya." 20

Adapun mazhab Hambali melihat bahwa musafir yang sedang menyelesaikan suatu urusan dan tidak kunjung selesai maka dibolehkan untuk mengqasar salat selama delapan belas hari selain dua hari saat masuk dan keluar dari suatu daerah. Karena, Rasulullah saw. pernah bermukim di Mekkah saat menaklukkan kota Mekkah untuk mengikuti perang Hawazin, dan beliau mengqasar salatnya.

\section{Latar Belakang Perbedaan Pendapat Empat Ulama Mazhab dalam Masalah Penetapan Batas Waktu Mengqasar Salat bagi Musafir}

Ibnu Rusyd dalam kitabnya menjelaskan bahwa silang pendapat para ulama

\footnotetext{
${ }^{16} \mathrm{Abu}$ 'Abdillah Muhanunad bin Idris bin al-'Abbas bin 'Usman bin Syafi'i al-Syafi'i, Al-Umm, Jilid I (t.tp.: Dar al-Ma'rifah, 1410 H/ 1990 M), h. 215.

${ }^{17}$ Muslim bin Hajjaj, Sậih Muslim. Jilid 2, h. 985.

${ }^{18}$ Muhammad ibn 'Ali ibn Muahammad ibn 'Abdillah al-Syaukâni al-Yamâni, Nail al-Autar, Jilid III (cet. I; Mesir: Dâr al-Hâdis, 1993 M/ 1413 H), h. 248.

${ }^{19}$ Syihabuddin Ahmad bin Hajar al-Haitami, Tuhfat al-Muhtaj bi Syarh al-Minhaj, Jilid 2, h. 411. h. 106-107.

${ }^{20}$ Abdul Qani al Qanīmi, al-Lubab fi Syarh al-Kitab, Jilid 1 (Bairut: al-Maktabah al-'Ilmiyah, t.th.),
} 
tentang batas waktu seorang musafir yang tinggal di suatu daerah boleh mengqasar salat, merupakan silang pendapat yang panjang. Tentang masalah tersebut seperti yang telah dikatakan oleh Abu Umar paling kurang terdapat sebelas pendapat di kalangan ulama. ${ }^{21}$

Sebab terjadinya perbedaan tersebut karena persoalan ini termasuk masalah yang tidak dibahas secara tegas dalam syariat ('amrun maskuutun 'anhu fi al-syar'i). Sementara menurut ulama, qiyas yang membatasi masalah ini adalah lemah. Oleh karena itu, masing-masing ulama yang berbeda pendapat tersebut berpedoman pada kondisi dan tindakan yang dikutip dari Nabi saw. Perbedaan pendapat tentang batas waktu qasar salat terjadi karena adanya perbedaan pandangan mengenai hadis-hadis yang digunakan oleh masing-masing mazhab.

\section{Pendapat Rajih dalam Masalah Penetapan Batas Waktu Mengqasar Salat bagi Musafir}

Sebagaimana ibadah-ibadah lain dalam Islam, ibadah salat telah ditentukan batas waktu dalam pelaksanaannya, sehingga tidak sah apabila salat dilakukan bukan pada waktumya. Dalam melakukan salat qasar memerlukan adanya batasan waktu karena masyaqqah yang ditimbulkan akibat bepergian tersebut. Apabila diperbolehkan tanpa adanya batasan waktu, maka seseorang dapat melalaikan kewajiban salatnya. Dalam Q.S. al-Nisa'/4: 101, Allah tidak menyebutkan secara khusus tentang batasan bepergian dan kebolehan melakukan salat qasar bagi musafir. Maka lahiriah dari ayat itu bersifat mutlak bahwa salat qasar tidak dibatasi. Namun ketika dicermati dalil-dalil dari sunnah, maka disinilah terdapat perbedaan antara satu riwayat dengan riwayat yang lain.

Jika diperhatikan dengan seksama pendapat mazhab Hambali kurang lebih bersesuaian dengan pendapat yang dikemukakan oleh mazhab Maliki dan Syafii. Namun yang membedakan adalah mazhab Maliki dan Syafii tidak memperhitungkan hari di mana musafir masuk di tempat mukimnya, juga hari di mana musafir tersebut keluar dari tempat tersebut. Sementara mazhab Hambali memperhitungkan waktu masuk dan keluarnya dari tempat mukimnya. Kemudian pendapat mazhab Hanafi cenderung berdiri sendiri.

Mazhab Hanafi berpendapat batas bolehnya mengqasar salat adalah selama lima belas hari. Sedangkan menurut mazhab Syafii boleh melakukan qasar selama empat hari. Perbedaan pendapat kedua mazhab ini menunjukkan bahwa masing-masing memiliki alasan atau dasar hukum dalam menentukan batas waktu bolehnya mengqasar salat. ${ }^{22}$ Mazhab Hanafi berpedoman pada hadis Rasulullah saw. yang diriwayatkan oleh Ibnu Majah dari Ibnu Abbas yang mengatakan bahwa Rasulullah saw. tinggal di Mekkah pada peristiwa penaklukan Mekkah lima belas hari dan beliau mengqasar salat. Pada atsar sahabat dari Ibnu Umar dan Ibnu Abbas, keduanya berkata, "Jika kamu memasuki sebuah daerah dan kamu sedang bepergian, lalu kamu berniat untuk bermukim di daerah tersebut selama lima belas hari maka sempurnakanlah salat. Namun jika kamu tidak tahu kapan akan berangkat lagi maka tetap qasarlah salatmu." Sedangkan mazhab Syafii berpedoman pada hadis yang diriwayatkan oleh Bukhari dan Muslim dari al-'Alla' alHadrami yang mengatakan bahwa Rasulullah saw. bersabda, "Untuk para muhajirin itu

\footnotetext{
${ }^{21}$ Muhammad ibn Ahmad ibn Muhammad ibn Ahmad lbnu Rusyd, Bidayah al-Mujtahid wa Nihayah al-Muqtasid, Jilid I, h. 147.

${ }^{22}$ Muhammad Amin al-Syahir, Radd al-Mukhtar wa Dár al-Muhtaar, Jilid 2 (Riyaḍ: Dár al-‘alimil Kutub, 2003), h. 601
} 


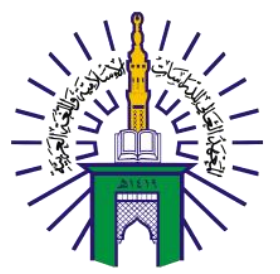

\section{BUSTANUL FUQAHA: \\ JURNAL BIDANG HUKUM ISLAM \\ Vol. 2 No. 1 (2021): Hal. 500-508 \\ EISSN: 2723-6021 \\ Website: https://journal.stiba.ac.id}

bermukim tiga hari di Mekkah setelah menunaikan manasik haji.'”

Menurut pandangan mazhab Hanafi, hadis tentang Nabi saw. memberi izin tiga hari bagi muhajirin yang digunakan oleh mazhab Syafii tidak menunjukkan batasan maksimal boleh qasar salat adalah tiga hari. Karena Nabi mengetahui hajat-hajat muhajirin dapat terpenuhi dalam waktu tiga hari bukan berarti Nabi saw. menentukan masa minimal bermukim. ${ }^{23}$

Dalam hadis Rasulullah saw. bersabda:

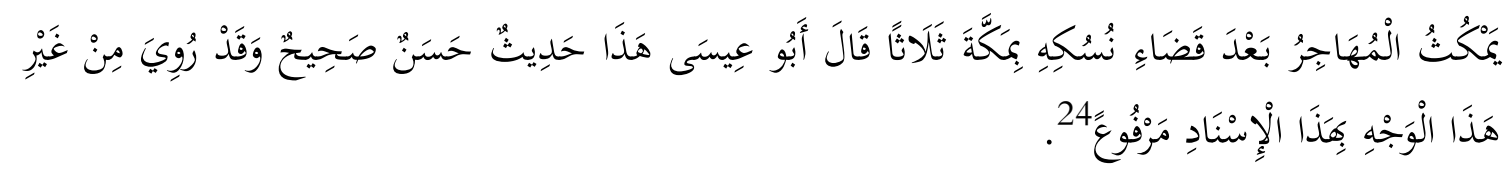

Artinya:

Orang yang pindah (muhajir) boleh tinggal, setelah selesai melaksanakan seluruh manasiknya di Makkah selama tiga hari." Abu 'Isa berkata; "Ini merupakan hadits hasan shahih dan telah diriwayatkan melalui jalur lain dengan sanad yang sama secara marfu'.

Mazhab Syafii menyanggah dalil yang digunakan oleh mazhab Hanafi yaitu hadis riwayat dari Ibnu Abbas tentang batas qasar salat selama lima belas hari. Beliau mengatakan bahwa ini adalah pendapat sahabat dan ada sahabat lain yang berbeda dengannya. Imam al-Nawawi dalam kitab Majmu, menggolongkan hadis ini kepada hadis daif. ${ }^{25}$ Oleh karena itu, hadis ini tidak bisa dijadikan sebagai dalil.

Adapun pada kasus seorang musafir yang bermukim di suatu tempat dan ia berencana akan meninggalkan tempat tersebut besok, bila tugas sudah selesai dan hal ini terus berlangsung sampai jangka waktu yang tidak diketahui. Mazhab Hanafi berpendapat boleh melakukan qasar selama jangka waktu yang belum diketahui tersebut. Dalam hal ini pada praktek sahabat berbeda-beda. Ada sebagian sahabat yang menetap dua bulan, enam bulan, satu tahun dan mereka senantiasa melakukan qasar salat. Sedangkan mazhab Syafii menurut pendapat yang kuat dalam kitab Tuhfah al-Muhtaj boleh mengqasar selama delapan belas hari, tidak termasuk hari berangkat dan pulang. Nabi saw. mengqasar salat selama delapan belas hari sesudah fathu Mekkah di perang Hawazin. Mazhab Syafii menakwil hadis sahih yang menyatakan selain dari delapan belas hari, baik hadis dua puluh hari, sembilan belas hari, atau tujuh belas hari dan lima belas hari. Sedangkan di dalam kitab Syarh al-Muhazzab, Imam al-Nawawi menerangkan boleh qasar selama tujuh belas hari dan ia juga menakwil hadis yang menyatakan selain tujuh belas hari. ${ }^{26}$

Dari pandangan yang dikemukakan oleh beberapa mazhab tersebut tentang batas lama boleh mengqasar salat bagi musafir yang bermukim, nampak pendapat yang kuat dan rajih adalah pandangan mazhab Syafii yang membatasi tiga hari karena dalil-dalil yang digunakannya sangat kuat.

${ }^{23}$ Muhammad bin Ahmad bin Abi Sahi al-Sarakhasi, al-Mabsūt. Jilid I (t.Cet; Beirut: Dar alMa'rifah, 1993 M), h. 235.

${ }^{24}$ Muslim bin al-Hajjaj, al-Jami' al-Sohih, no.3933, h.144.

${ }^{25}$ Yahya bin Syaraf al-Nawawi, Al-Majmu' Syarhu al-Muhazzab, Jilid IV (t.tp.: Dar al-Fikri, t.th), h. 328 .

${ }^{26}$ Muhammad Abdillah bin Ahmad, al-Muqhniy, h.147-149. 


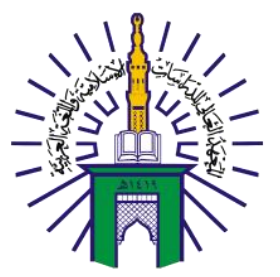

\section{BUSTANUL FUQAHA: \\ JURNAL BIDANG HUKUM ISLAM \\ Vol. 2 No. 1 (2021): Hal. 500-508 \\ EISSN: 2723-6021 \\ Website: https://journal.stiba.ac.id}

\section{KESIMPULAN}

Salat qasar merupakan rukhsah dari Allah bagi mereka yang sedang melakukan perjalanan atau dalam keadaan penuh ketidakamanan. Namun ulama empat mazhab berbeda pandangan tentang penetapan batas waktu mengqasar salat bagi musafir. Sebabnya karena persoalan ini termasuk masalah yang tidak dibahas secara tegas dalam syariat ( 'amrun maskuutun 'anhu fi al-syar'i). Hal ini memicu adanya perbedaan pandang mengenai hadis-hadis Rasulullah saw. tentang safar.

Mazhab Hanafi: seorang musafir boleh mengqasar salatnya selama lima belas hari. Mazhab Maliki dan Syafii; seorang musafir boleh mengqasar salatnya selama empat hari selain hari kedatangan dan kepergiannya. Mazhab Hanbali: seorang musafir boleh mengqasar salatnya selama empat hari atau dua puluh waktu salat wajib, termasuk di dalamnya hari kedatangan dan kepergiannya. Namun, pandangan yang paling rajih adalah mazhab Syafii dan Maliki.

\section{DAFTAR PUSTAKA}

Al-Khurasam, Abu 'Abdirrahman Ahmad ibn Syu'aib ibn 'Ali. Al-Sunan al-Sughra alNasa'i. Jilid III, Cet.II; Halib: Maktab al-Matbu’at al-Islamiyyah, 1406 H/ 1986 M.

Al-Naisaburi, Muslim ibn al-Hajjaj Abu al-Hassan al-Qusyairi. Al-Jami' al-Sahih, Jilid I. Beirut: Dar Ihya al-Turasi al-'Arabiy, t.th.

Al-Nawawi, Abu Zakariyya Muhyiyu al-Dih Yahya bin Syaraf . Al-Majmu' Syarhu alMuhazzab. Jilid IV. t.tp.: Dar al-Fikri, t.th.

Al-Samarqandi, Muhammad Ahmad ibn Abi Ahmad Abu Bakr 'Ila'uddin. Tuhfatu alFuqah. Jilid I, Cet. II; Beirut: Dar al-Kitab al-'Ilmiyyah, 1414 H/ 1994 M.

Al-San'am, Muhammad ibn 'Ismail ibn Salah ibn Muhammad. Subul al-Salam. Jilid I; t.tp.: Dar al-Hadis, t.th.

Al-Sarakhasi, Muhammad bin Ahmad bin Abi Sahi. Al-Mabsut. Jilid I. Beirut: Dar alMa'rifah, 1414 H/ 1993 M

Al-Syafii, Abu 'Abdillah Muhammad bin Idris bin al-'Abbas bin 'Usman bin Syafii . AlUmm. Jilid I, t.tp.: Dar al-Ma'rifah, 1410 H/1990 M.

Al-Yamâni, Muhammad ibn 'A1i ibn Muhammad ibn 'Abdillah al-Syaukāni. Nail alAutar. Jilid III, Cet. I; Mesir: Dâr al-Hâdis, 1993 M/ 1413 H.

Al-Zuhail, Wahbah bin Mustafa. Al-Fiqh al-Islami wa Adillatuh. Jilid II, Cet. IV; Damaskus: Dar al-Fikri, t.th.

'Departemen Agama, Al-Quran Terjemah. Banten: CV. Al-Fatih Berkah Cipta, 2016

Ikhsan, Muhammad. Sejarah Mazhab Fikih di Asia Tenggara. Nukhbatul 'Ulum 4, no. 67 (2018).

Kasir, Abu al-Fida' 'Isma'il Ibnu 'Umar Ibnu. Tafsir al-Quran al-Âzım. Jilid III. Cet. III; t.tp.: Dâr al-Tayyibah li al-Nusyr wa al-Tauzf, 1420H/ 1999 M.

Rusyd,, Abu al-Walid Muhammad ibn Ahmad. Bidayah al-Mujtahid wa Nihayah alMuqtasid, Jilid I. Kairo: Dar al-Hadis, 1425 H/ 2004 M. 